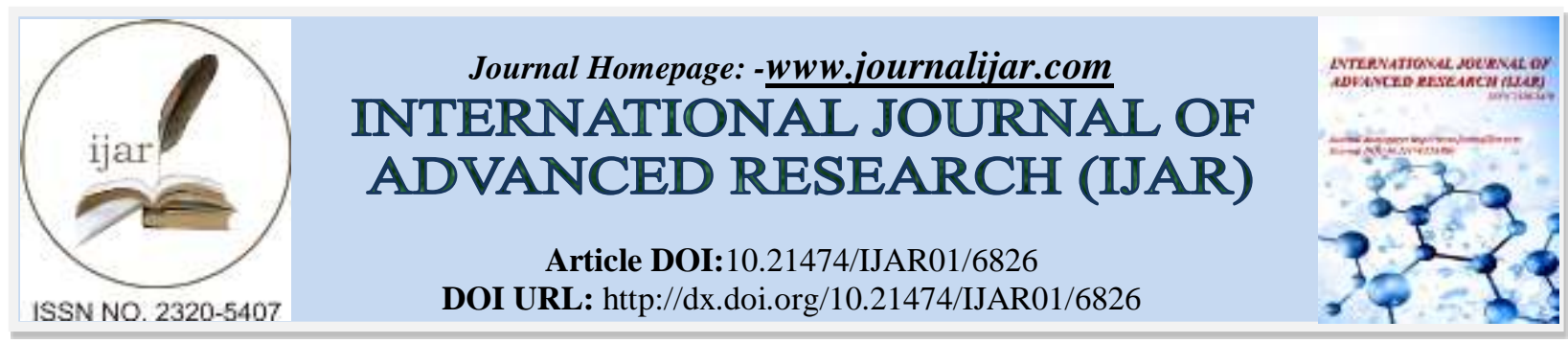

RESEARCH ARTICLE

\title{
CHEMICAL CHARACTERISTIC AND ACCEPTANCE OF KEPOK BANANA COOKIES (MUSA PARADISIACA) WITH THE ADDITION OF CINNAMON (CINNAMOMUM BURMANNII BL.) POWDER
}

Rina Yenrina, Alfi Asben and Mia Meliza.

Faculty of Agricultural Technology, Andalas University, Limau Manis Campus-Padang, Indonesia 25163.

\section{Manuscript Info}

Manuscript History

Received: 02 February 2018

Final Accepted: 04 March 2018

Published: April 2018

Keywords:-

Characteristic, Acceptance, Cookies,

Banana, Cinnamon.

\section{Abstract}

This research was aim to know the chemical characteristic and acceptance of Kepok Banana cookies with the addition of cinnamon. This research used Completely Random Design (CDR) consists of 5 treatments and 3 replications, Percentage of cinnamon powder used : $\mathrm{A}(0.5 \%), \mathrm{B}(1.0 \%), \mathrm{C}(1.5 \%), \mathrm{D}(2.0 \%)$ and $\mathrm{E}(2.5 \%)$. Raw material observation were water content, starch content and ash content. The observation of cookies were water content, ash content, protein content, fat content, carbohydrates content, crude fiber content, antioxidant activity. Result of this research shown that the addition of cinnamon significantly effected on water content, ash content, carbohydrates content, protein content and antioxidant activity. There was not significantly effected to fat content, crude fiber content. The result of sensory test showed the $\mathrm{C}$ treatment with additional cinnamon powder $(1.5 \%)$ was the best product with score of color 3.93, aroma 3.87, taste 4.90 and texture 3.67. The formulation of $\mathrm{C}$ treatment with additional cinnamon powder $(1,5 \%)$ with rate of water content $(3.57 \%)$, ash content $(2.49 \%)$, protein content $(5.73 \%)$, fat content $(15.44 \%)$, carbohydrates content (72.77\%), crude fiber content $(1.96 \%)$, antioxidant activity $(77.80 \%)$.

Copy Right, IJAR, 2018,. All rights reserved.

\section{Introduction:-}

Many efforts to support national food security programs are conducted to maximize the production and consumption of local food sources of non-rice and non-wheat carbohydrates that are priorities of the government, especially in the field of diversification. The current diversification of food consumption is not just to provide a diverse and nutritious food, but it has begun to develop to the consideration of health benefits.

Cookies are a kind of biscuit or pastry, made with a high-fat, crunchy soft dough and if it, broken it has texture solid, can be made with cute little shapes (U.S Wheat Associate 1981) ${ }^{1}$.

Banana is one type of horticulture commodity in the form of fruits that have high economic value for the people in Indonesia because among others, bananas as a good source of pro vitamin A, banana as the main source of calories besides avocado and durians, bananas are well known by the public, banana cultivation can be done anywhere and quickly growing. In addition, banana commodities also have great opportunities to be used in various industries (Mulyati, 2005) ${ }^{2}$. 
Banana kepok (Musa paradisiaca) is a product that is quite perspectively in the development of local food sources because bananas can grow in various places so that the fruit production is always available, but quickly damaged after the harvest time, to overcome the damage it can be processed into food that is more resistant, one of which is cookies. Before processed into banana cookies the banana processed into flour first (Satuhu and Supriyadi, 1999) ${ }^{3}$.

The making of banana flour in beside to extend the shelf life, also to facilitate and expand the development of the use of bananas as foodstuffs such as for cakes, chips, bread, pastry products and others (Hardiman, 1982) ${ }^{4}$.

In the utilization of banana flour (Musa paradisiaca) as the ingredients of making non-wheat biscuits was given the addition of cinnamon powder that has many benefits, where the main component of cinnamon flavor is cinnamaldehyde, a group of oxygenated hydrocarbons that become the most important component in providing flavor and aroma.

The bark of cinnamon has a spicy and sweet taste, good fragrant, and is warm. Some chemicals contained in cinnamon include eugenol essential oil, safrole, sinamaldehide, calcium oxalate. (Rismunandar and Paimin, 2001) ${ }^{5}$

According to Indah $(2013)^{6}$, about the effect of adding cinnamon bark concentration to breadfruit leaves tea with $2 \%, 4 \%, 6 \%, 8 \%$ and $10 \%$ treatment, the highest antioxidant activity was $10 \%$. According to research by Rohmah $(2010)^{7}$ which mix robusta coffee powder on leaf and cinnamon bark powder with treatment of $2 \%, 4 \%, 6 \%, 8 \%$ and $10 \%$. High antioxidant activity was found in the treatment of $10 \%$ of leaf and cinnamon bark powder / $100 \mathrm{~g}$ of coffee powder and the result of antioxidant activity obtained by DPPH method was $51,72 \%$. From preliminary research conducted with $2 \%$ cinnamon used, resulting in a strong cassiavera flavor, so that the used of cinnamon was reduced.

\section{Methodology:-}

This research was conducted in Laboratory of Chemistry, Biochemistry and Food Nutrition, Laboratory of Microbiology and Biotechnology of Agricultural Products, Instrumentation Laboratory and Laboratory of Engineering and Process of Agricultural Product Technology of Agricultural Technology Faculty of Andalas University.

\section{Materials and Tools:-}

The tools used were oven, thermometer, slicer, plastic container, baker glass, measuring cylinder, analytical scales, sieve/sifter, timer, stove, pot, jar, mixer and container. Analyzer used are oven moisture, furnace, kjeldahl, hot plate, erlenmeyer, measuring cup and analytical scale.

The materials used in this research were slightly mature kepok bananas, margarine, granulated sugar, water, baking soda, baking powder, salt, tapioca flour, corn starch, vanilla and cinnamon in powder form.

\section{Research Design:-}

The research design used in this research was Completely Randomized Design (CDR) with 5 treatments 3 replications. Then proceed with Duncan's Multiple Range Test (DNMRT) test at 5\% real level. The treatment used in this study were as follows:

Treatment $\mathrm{A}=$ addition $0.5 \%$ cinnamon powder

Treatment $\mathrm{B}=$ Addition $1.0 \%$ cinnamon powder

Treatment $\mathrm{C}=$ Addition $1.5 \%$ cinnamon powder

Treatment $\mathrm{D}=$ Addition $2.0 \%$ cinnamon powder

Treatment $\mathrm{E}=$ Addition $2.5 \%$ cinnamon powder

\section{Research Implementation:-}

Making of Banana Flour (Rukmana, 1999) ${ }^{8}$ :-

Making of banana kepok flour was began with choosing bananas that mature enough but not ripe yet washed and cleaned of dirt. Bananas steamed for 10 minutes to ease the stripping process and to remove the sap and improved the color of the resulting flour. After that the bananas cooled and peeled and weighed. Furthermore bananas sliced used a slicer with a thickness of $0.1 \mathrm{~cm}$ then soaked in $2.000 \mathrm{ppm}$ of sodium bisulfite solution about 5-10 minutes to prevent browning to be durable. After that the banana slices placed on the container and dried with oven with 
temperature of $60-70{ }^{0} \mathrm{C}$ for 10 hours. The dried banana slices then mashed with a blender. Powdered banana then sifted used a 60 mesh sieve, then obtained banana flour.

Making of Cookies (Modified Manley, 2000) ${ }^{9}:-$

1. Butter, egg yolk and refined sugar mixed with mixer for 5 minutes. 2. Added banana flour, cornstarch, tapioca flour, skim milk, vanilla, salt and baking powder and cinnamon powder and mixed again for 2 minutes with mixer.

2. After the dough was formed, allowed for 5 minutes to relax the dough.

3. The dough was flattened with a thickness $\quad$ of $0.5 \quad$ cm. 5. The dough then molded and placed on the baking sheet. The molded product was baked for 15 minutes with a temperature of $180^{\circ} \mathrm{C}$, removed from the oven and cooled for 10 minutes, and after it cooled, put in an airtight

The formula for making cookies can be seen in Table 1. container.

Table 1:- Formulation of Cookies

\begin{tabular}{|l|c|c|c|c|c|}
\hline \multirow{2}{*}{ Composition (g) } & \multicolumn{5}{c|}{ Treatment } \\
\cline { 2 - 6 } & $\mathrm{A}$ & $\mathrm{B}$ & $\mathrm{C}$ & $\mathrm{D}$ & $\mathrm{E}$ \\
\hline Banana flour & 100 & 100 & 100 & 100 & 100 \\
\hline Tapioca flour & 50 & 50 & 50 & 50 & 50 \\
\hline Cornstarch & 50 & 50 & 50 & 50 & 50 \\
\hline Cinnamon & 0.5 & 1.0 & 1.5 & 2.0 & 2.5 \\
\hline Margarine & 60 & 60 & 60 & 60 & 60 \\
\hline Sugar Flour & 30 & 30 & 30 & 30 & 30 \\
\hline Egg Yolk & 35 & 35 & 35 & 35 & 35 \\
\hline Vanilla & 1 & 1 & 1 & 1 & 1 \\
\hline Salt & 1 & 1 & 1 & & 1 \\
\hline Baking powder & 0.3 & 0.3 & 0.3 & 0.3 & 0.3 \\
\hline Skim milk & 5 & 5 & 5 & 5 & 5 \\
\hline
\end{tabular}

\section{Observations:-}

Observations that made in this study were conducted in two stages, namely observation on raw materials of banana flour which included water content analysis, starch content and ash content. Then the observation of the cookies that included:

1. Organoleptic test: 3 best treatment followed by chemical analysis..

2. Chemical analysis: water content (gravimetric), ash content (gravimetric), protein content (kjeldahl), fat content (Soxhlet), carbohydrate content (luff school), crude fiber content (gravimetric), antioxidant activity (DPPH)

\section{Result And Discussion:-}

\section{Raw Material Analysis:-}

Analyzes that were conducted on raw materials of banana flour included moisture content, starch content and ash content. Analysis of raw material of Banana Flour can be seen in Table 2.

The result of water content analysis of banana flour obtained by $9.30 \%$. When compared with research by Pulungan $(2015)^{10}$, water content of banana flour obtained by $7.56 \%$ then the water content of banana flour produced was higher. According to SNI 01-3841-1995 ${ }^{11}$ about Banana Flour the water content had fulfilled the requirements with a maximum of $12 \%$. This was due to the drying process of the banana by using a cabinet dryer with a temperature of $60-70{ }^{0} \mathrm{C}$ for 10 hours, so that the water content obtained was lower, with a low water content it has physical and chemical advantages that is a long shelf life.

Carbohydrates in banana flour were mostly starch. The content of starch in banana flour was quite high at $67.33 \%$. The content of starch in banana flour was high enough this was because the raw material used was green mature banana. In green mature bananas, the starch that formed during the photosynthesis process has not been converted into simple sugar. 
The ash content of banana flour obtained was $2.58 \%$. When compared with the study of Pulungan (2015) ${ }^{10}$, the ash content obtained was $2.60 \%$. This meant that banana flour in this study had a value of ash content not vary much with the study of Pulungan (2015) ${ }^{10}$.

Table 2:- Average Value of Raw Material Banana Flour

\begin{tabular}{|l|c|}
\hline Component $(\%)$ & Result \\
\hline Yield & 35.26 \\
\hline Water & 9.30 \\
\hline Starch & 67.33 \\
\hline Ash & 2.58 \\
\hline
\end{tabular}

Table 3:- Average Value of Organoleptic Test on the Taste of Cookies

\begin{tabular}{|c|c|}
\hline Treatments & Taste Value \pm SD \\
\hline D (2.0\%) Cinnamon powder & $3.20 \pm 0.76$ a \\
\hline E $(2.5 \%)$ Cinnamon powder & $3.31 \pm 0.79 \quad \mathrm{a}$ \\
\hline A $(0.5 \%)$ Cinnamon powder & $3.36 \pm 0.89 \quad \mathrm{a}$ \\
\hline B (1.0\%) Cinnamon powder & $3.58 \pm 0.76 \mathrm{ab}$ \\
\hline $\mathrm{C}(1.5 \%)$ Cinnamon powder & $3.86 \pm 0.68 \quad b$ \\
\hline $\mathrm{CV}=21.97 \%$ & \\
\hline
\end{tabular}

Table 4:- Average Value of Organoleptic Test on the Texture of Cookies

\begin{tabular}{|l|c|}
\hline Treatments & Texture Value \pm SD \\
\hline B $(1.0 \%)$ Cinnamon powder & $3.53 \pm 0.72$ \\
\hline D $(2.0 \%)$ Cinnamon powder & $3.57 \pm 0.80$ \\
\hline E $(2.5 \%)$ Cinnamon powder & $3.60 \pm 0.81$ \\
\hline C $(1.5 \%)$ Cinnamon powder & $3.67 \pm 0.63$ \\
\hline A $(0.5 \%)$ Cinnamon powder & $3.67 \pm 0.76$ \\
\hline CV $=20.77 \%$ & \\
\hline
\end{tabular}

Table 5:- Average Value of Organoleptic Test on the Color of Cookies

\begin{tabular}{|l|c|}
\hline Treatments & Color Value \pm SD \\
\hline E $(2.5 \%)$ Cinnamon powder & $3.14 \pm 0.95 \mathrm{a}$ \\
\hline $\mathrm{D}(2.0 \%)$ Cinnamon powder & $3.56 \pm 0.72 \mathrm{~b}$ \\
\hline A $(0.5 \%)$ Cinnamon powder & $3.67 \pm 0.71 \mathrm{~b}$ \\
\hline B $(1.0 \%)$ Cinnamon powder & $3.74 \pm 0.68 \mathrm{~b}$ \\
\hline C $(1.5 \%)$ Cinnamon powder & $3.90 \pm 0.71 \mathrm{~b}$ \\
\hline CV $=20.88 \%$ & \\
\hline
\end{tabular}

Table 6:- Average Value of Organoleptic Test on the Aroma of Cookies

\begin{tabular}{|l|c|}
\hline Treatments & Aroma Value \pm SD \\
\hline $\mathrm{D}(2.5 \%)$ Cinnamon powder & $3.33 \pm 0.80 \mathrm{a}$ \\
\hline $\mathrm{E}(2.5 \%)$ Cinnamon powder & $3.34 \pm 0.81 \mathrm{a}$ \\
\hline $\mathrm{B}(1.0 \%)$ Cinnamon powder & $3.64 \pm 0.75 \mathrm{ab}$ \\
\hline $\mathrm{A}(0.5 \%)$ Cinnamon powder & $3.67 \pm 0.76 \mathrm{ab}$ \\
\hline $\mathrm{C}(1.5 \%)$ Cinnamon powder & $3.83 \pm 0.83 \mathrm{ab}$ \\
\hline $\mathrm{CV}=20.88 \%$ & \\
\hline
\end{tabular}

Table 7:- Average Value of Water content of Cookies

\begin{tabular}{|l|c|}
\hline Treatments & $\begin{array}{c}\text { Water Content }(\%) \\
\text { (Average } \pm \text { SD) }\end{array}$ \\
\hline C $(1.5 \%)$ Cinnamon powder & $3.57 \pm 0.11 \mathrm{a}$ \\
\hline B $(1.0 \%)$ Cinnamon powder & $4.57 \pm 0.19 \mathrm{~b}$ \\
\hline A $(0.5 \%)$ Cinnamon powder & $5.46 \pm 0.23 \mathrm{c}$ \\
\hline CV $=4.04 \%$ & \\
\hline
\end{tabular}


Table 8:- Average Value of Ash content of Cookies

\begin{tabular}{|l|l|}
\hline Treatments & \multicolumn{1}{c|}{$\begin{array}{c}\text { Ash Content }(\%) \\
\text { (Average } \pm \text { SD) }\end{array}$} \\
\hline B $(1.0 \%)$ Cinnamon powder & $1.74 \pm 0.01 \mathrm{a}$ \\
\hline A $(0.5 \%)$ Cinnamon powder & $1.84 \pm 0.04 \mathrm{a}$ \\
\hline C $(1.5 \%)$ Cinnamon powder & $2.49 \pm 0.15 \quad \mathrm{~b}$ \\
\hline $\mathrm{CV}=4.65 \%$ & \\
\hline
\end{tabular}

Table 9:- Average Value of Protein content of Cookies

\begin{tabular}{|l|l|}
\hline \multicolumn{1}{|c|}{ Treatments } & \multicolumn{1}{c|}{$\begin{array}{c}\text { Protein Content (\%) } \\
\text { (Average } \pm \text { SD) }\end{array}$} \\
\hline $\mathrm{C}(1.5 \%)$ Cinnamon powder & $5.73 \pm 0.19 \mathrm{a}$ \\
\hline $\mathrm{B}(1.05)$ Cinnamon powder & $6.62 \pm 0.27 \mathrm{~b}$ \\
\hline $\mathrm{A}(0.5 \%)$ Cinnamon powder & $7.12 \pm 0.23 \mathrm{c}$ \\
\hline $\mathrm{CV}=3.90 \%$ & \\
\hline
\end{tabular}

Table 10:- Average Value of Fat content of Cookies

\begin{tabular}{|l|c|}
\hline \multicolumn{1}{|c|}{ Treatments } & $\begin{array}{c}\text { Fat Content (\%) } \\
\text { (Average } \pm \text { SD) }\end{array}$ \\
\hline $\mathrm{C}(1.5 \%)$ Cinnamon powder & $15.44 \pm 0.78$ \\
\hline $\mathrm{B}(1.0 \%)$ Cinnamon powder & $15.32 \pm 0.89$ \\
\hline $\mathrm{A}(0.5 \%)$ Cinnamon powder & $15.13 \pm 0.40$ \\
\hline $\mathrm{CV}=6,25 \%$ & \\
\hline
\end{tabular}

Table 11:- Average Value of Carbohydrate content of Cookies

\begin{tabular}{|l|l|}
\hline \multicolumn{1}{|c|}{ Treatments } & \multicolumn{1}{c|}{$\begin{array}{c}\text { Carbohydrate content (\%) } \\
\text { (Average } \pm \text { SD) }\end{array}$} \\
\hline $\mathrm{A}(0.5 \%)$ Cinnamon powder & $70.44 \pm 0.37 \mathrm{a}$ \\
\hline $\mathrm{B}(1.0 \%)$ Cinnamon powder & $71.73 \pm 0.97 \mathrm{ab}$ \\
\hline $\mathrm{C}(1.5 \%)$ Cinnamon powder & $72.77 \pm 0.92 \mathrm{~b}$ \\
\hline $\mathrm{CV}=1.15 \%$ & \\
\hline
\end{tabular}

Table 12:- Average Value of Crude Fiber content of Cookies

\begin{tabular}{|l|c|}
\hline \multicolumn{1}{|c|}{ Treatments } & $\begin{array}{c}\text { Crude Fiber Content }(\%) \\
\text { (Average } \pm \text { SD) }\end{array}$ \\
\hline A $(0.5 \%)$ Cinnamon powder & $1.68 \pm 0.14$ \\
\hline B $(1.0 \%)$ Cinnamon powder & $1.90 \pm 0.86$ \\
\hline C $(1.5 \%)$ Cinnamon powder & $1.96 \pm 0.87$ \\
\hline CV $=27.43 \%$ & \\
\hline
\end{tabular}

Table 13:- Average Value of Antioxidant Activity of Cookies

\begin{tabular}{|l|c|}
\hline \multicolumn{1}{|c|}{ Treatments } & Antioxidant Activity (\%) ( Average \pm SD) \\
\hline A $(0.5 \%)$ Cinnamon powder & $55.03 \pm 3.03 \mathrm{a}$ \\
\hline $\mathrm{B}(1.0 \%)$ Cinnamon powder & $73.29 \pm 3.28 \mathrm{~b}$ \\
\hline $\mathrm{C}(1.5 \%)$ Cinnamon powder & $77.80 \pm 1.26$ \\
\hline $\mathrm{CV}=3.90 \%$ & $\mathrm{~b}$ \\
\hline
\end{tabular}

Note:

Numbers in the same column followed by different letters showed significantly different according to DNMRT at a real $5 \%$ level.

1 = Dislike Extremely (STS), 2 = Dislike (TS), 3 = Ordinary (B), $4=$ Like (S), $5=$ Like Extremely

Analysis of Acceptance of Banana Flour Cookies with the addition of Cinnamon Powder Organoleptic Test:- 
The organoleptic test can determine the panelist's acceptance level of cookies produced by observing the taste, texture, color, and aroma of 30 semi-trained panelists.

The organoleptic test performed using a hedonic test with hedonic scale 1 to 5 is $1=$ Dislike Extremely (STS), $2=$ Dislike (TS), 3 = Ordinary (B), $4=$ Like (S), $5=$ Like Extremely (SS). In determining the most preferred product was done by averaging the value of the number of panelists who express likes and dislikes and the highest average value was expressed as the best product.

\section{Taste:-}

Based on Table 3. it can be seen that the average value on taste by panelist the most prefered product by panelists was cookies with treatment $\mathrm{C}$ (1.5\% cinnamon powder addtion) with an average organoleptic value of 3.84 , followed by cookies B and treatment A with an average value of organoleptic acceptance of 3.61 and 3.59, whereas treatment D and treatment $\mathrm{E}$ had an average value of organoleptic acceptance of 3.42 and 3.34. The taste of banana cookies with the addition of cinnamon powder tend to taste spicy, because this spicy flavor came from cinnamon powder containing essential oils (Rismunandar and Paimin 2001).

\section{Texture:-}

Organoleptic test results on cookies texture made from banana kepok flour showed that the addition of cinnamon powder had no significant effect at the 5\% level. In Table 4 it can be seen that the most preferred texture was treatment $\mathrm{A}$ and treatment $\mathrm{C}$ where banana flour cookies with $0.5 \%$ and $1.5 \%$ cinnamon powder addition with an average of 3.67, followed by treatment $\mathrm{E}$ with average organoleptic value of 3.60. Treatment $\mathrm{B}$ and $\mathrm{D}$ with an average values of 3.53 and 3.57. The more cinnamon powder added, the better the resulting texture, because the cinnamon powder has a high enough fiber that affected the density of the cookies, so the cookies became vulnerable (Rismunandar and Paimin, 2001) ${ }^{5}$.

\section{Color:-}

Organoleptic test results on the color of cookies made from banana kepok flour showed that the addition of cinnamon powder significantly affected at the level of 5\%. Based on Table 5 it can be seen that the most prefered color was cookies with $\mathrm{C}$ treatment (1.5\% cinnamon powder addition) with an average organoleptic value of 3.90 and the cookies color which was less favorable found in treatment E (2.5\% cinnamon powder addition) with the average value of 3,14 .

The addition of cinnamon powder affected the color of the resulting cookies, where the more the addition of cinnamon powder into the dough, the more browning the resulting cookie color. This was related to the color of the cinnamon that is seen visually brownish.

\section{Aroma:-}

The results of organoleptic test on the aroma of cookies made from banana kepok flour showed that the addition of cinnamon powder gave significant affect at the level of 5\%. Based on a panelist assessment, treatment D $(2.0 \%$ cinnamon powder addition) with an average of 3.33, was the lowest panelist acceptance of cookies aroma, while the treatment $\mathrm{C}$ (1.5\% cinnamon powder addition) showed the highest level of panelists' acceptance of cookie aroma with an average value of 3.83 , followed by treatment $\mathrm{A}$, treatment $\mathrm{B}$, and treatment $\mathrm{E}$ with an average value of 3.67; 3.64 ; and 3.34.

Based on the average value of organoleptic it can be concluded that the best product was the treatment $\mathrm{C}(1.5 \%$ cinnamon powder addition) with the average organoleptic test value of color 3.93; aroma 3.87; texture 3.67; and taste 3.90 (for treatment C).

To find out the most preferred product by panelists, it can also be seen on the basis of the organoleptic test radar against the average cookies preferences in each treatment. The organoleptic radar can be seen in Figure 1. From the radar known that the best product in sequence was product $\mathrm{C}, \mathrm{B}, \mathrm{A}, \mathrm{D}$ and $\mathrm{E}$. The best three of the product was done analysis include water content, ash content, fat content, carbohydrate, energy value and antioxidant activity test. 


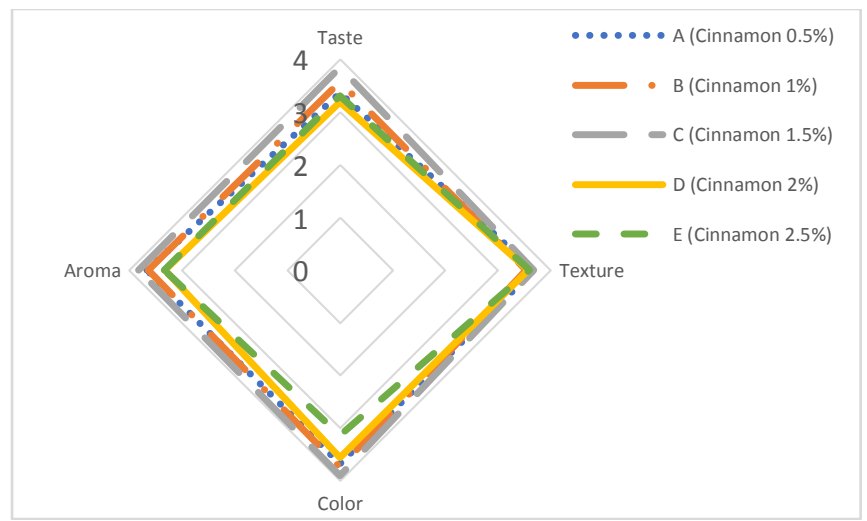

Figure 1:- Organoleptic Radar of Cookies Produced

\section{Chemical Analysis of Cookies of Banana Flour with Added of Cinnamon Powder:-}

Chemical analysis of the best three cookies products includes moisture content, ash content, protein content, fat content, carbohydrate levels, antioxidant activity, coarse fiber content

\section{Water Content:-}

Analysis result of water content of cookies made from banana flour with addition of cinnamon powder was $3.57 \%$ $5,46 \%$. The result showed that water content of cookies of banana powder with addition of cinnamon powder had a statistically significant effect $(\alpha<5 \% ; p=0.410)$.

Table 7 showed the highest water content found in treatment A ( $0.5 \%$ cinnamon powder addition) with water content of $5.46 \%$ and the lowest water content found in cookie with treatment $\mathrm{C}$ (1.5\% cinnamon powder addition) with a water content of $3.57 \%$. This increased in water content was thought to be due to absorption of cinnamon powder, the less the cinnamon powder given the higher the resulting moisture content.

According to SNI 01-2973-2011 ${ }^{11}$, about the quality requirements of cookies and biscuits attached that the maximum water content is $5 \%$. From the product of cookies produced with the addition of cinnamon powder had been obtained results that meet the SNI Quality Standard.

\section{Ash Content:-}

Analysis result of ash content of cookies with the addition of cinnamon powder produced was $1.74 \%-2.49 \%$. The results of the variance indicate that the ash content of banana cookies with the addition of cinnamon powder had a statistically significant effect $(\alpha<5 \% ; \mathrm{p}=0.000)$. Table 8 showed the highest ash content found in cookies with treatment $\mathrm{C}$ (1.5\% cinnamon powder addition) with ash content of $2.49 \%$ and treatment $\mathrm{B}(1.0 \%$ cinnamon powder addition) was cookies with the lowest ash content with ash content of $1.74 \%$. From the results concluded that the less cinnamon powder given, the more ash content of cookie products produced. This was because the cinnamon powder has a high mineral and fiber content which affected the ash content of the cookies (Rismunandar and Paimin 2001)

\section{Protein content:-}

Analysis result of protein content of banana cookies with the addition of cinnamon powder was $5.73 \%-7.12 \%$. The results of variance indicated that protein content of banana cookies with the addition of cinnamon powder had a statistically significant effect $(\alpha<5 \% ; p=0.001)$. Table 9 showed the highest protein content found in cookie with A treatment $(0.5 \%$ cinnamon powder addition) with a protein content of $6.87 \%$ and treatment $\mathrm{C}(1.5 \%$ cinnamon powder addition) was a cookie with the lowest protein content with a protein content of $5.73 \%$. The protein content obtained had met the Quality Requirement of Cookies according to SNI 2973: 2011 ${ }^{12}$ which is at least 5\%. This results indicated that the higher the addition of cinnamon powder, then the protein content of cookies became lower. Protein content in cookies came from banana kepok flour (4.4\%) and also came from milk and eggs that added.

\section{Fat content:-}

Analysis result of fat content of banana cookies and the addition of cinnamon powder was $15.44 \%-15.13 \%$. The results of variance indicated that the fat content of banana cookies with the addition of cinnamon powder was not 
statistically significant $(\alpha>5 \% ; p=0.355)$. Table 10 showed the highest content of fat found in cookie $\mathrm{C}(1.5 \%$ cinnamon powder addition) with carbohydrate content of $15.44 \%$ and treatment A $(0.5 \%$ cinnamon powder addition) was a cookie with the lowest fat content with fat content of $15.13 \%$. The main function of fat in the making of cookies is as an emulsifier, in addition fat also serves as a flavor maker and gives texture to the cookies. The more fat that was added to the dough, the more fragile the cookies produced.

\section{Carbohydrate Content:-}

Analysis result of carbohydrate content of banana flour with the addition of cinnamon powder was $70.44 \%$ $72.77 \%$. The results of variance showed that carbohydrate content of banana cookies with the addition of cinnamon powder had a statistically significant effect $(\alpha>5 \% ; \mathrm{p}=0,038)$. Table 11 showed the highest carbohydrate content found in cookie treatment $C$ ( $1.5 \%$ cinnamon powder addition) with carbohydrate content of $72.77 \%$ and treatment A $(0.5 \%$ cinnamon powder addition) was cookies with the lowest carbohydrate content of $70.44 \%$. Carbohydrate content in cookies was calculated by determining carbohydrate content using by difference method. Carbohydrate content was calculated by difference influenced by other nutritional components, therefore the higher the other chemical components the carbohydrate content will be lower, and vice versa (Winarno, 2002) ${ }^{13}$.

\section{Crude Fiber Content:-}

Analysis result of crude fiber content of cookies made of banana kepok with the addition of cinnamon powder produced was $1.96 \%-1.68 \%$. The result of variance analysis showed that banana cookies with the addition of cinnamon powder was not statistically significant $(\alpha>5 \%, p=0,783)$ on crude fiber content. The highest crude fiber was found in treatment $\mathrm{C}$ (1.5\% cinnamon powder addition) and the lowest crude fiber content was found in treatment $\mathrm{A}(0.5 \%$ cinnamon powder addition) of $1.68 \%$. The more the addition of cinnamon powder to the cookies the higher the crude fiber content. This was due to the high fiber content of the cinnamon powder, while the fiber content of cinnamon powder was 29.1\% (Rismunandar and Paimin 2001) $)^{5}$.

\section{Antioxidant Activity:-}

Analysis result of antioxidant activity of banana cookies with the addition of cinnamon powder produced was $55.03 \%-77.80 \%$. The results of variance showed that antioxidant activity of banana flour cookies with the addition of cinnamon powder at 100,000 ppm concentration was statistically significant $(\alpha<5 \% ; p=0,000)$. Table 13 showed the highest antioxidant activity found in cookie with treatment $\mathrm{C}$ (1.5\% cinnamon powder addition) with antioxidant activity of $77.80 \%$ and treatment $\mathrm{A}(0.5 \%$ cinnamon powder addition) was cookies with the lowest antioxidant activity with antioxidant activity of $55.03 \%$. The more the addition of cinnamon powder the higher the antioxidant activity obtained. This was because cinnamon powder acted as an antioxidant because it contains tannin and eugenol compounds (Rismunandar, 1989) ${ }^{14}$

\section{Conclusions:-}

Based on the research that has been done to get some conclusions as follows:

1. The addition of cinnamon powder to cookies made from banana kepok was gave a significant effect on the ash content, moisture content, protein content, carbohydrate content and antioxidant activity. But it was not significant effect on the crude fiber content, fat content.

2. The level of panelist acceptance of cookies with the addition of cinnamon powder produced in sequence was $\mathrm{C}$, $\mathrm{B}, \mathrm{A}, \mathrm{D}$ and $\mathrm{E}$ of $1.5 \%, 1.0 \%, 0.5 \%, 2.0 \%$ and $2,5 \%$.

3. The best formulation was product $\mathrm{C}$ with the addition of $1.5 \%$ cinnamon powder of banana flour with nutrient content: moisture content of $3.57 \%$; ash content of $2.49 \%$; protein content of $5.73 \%$; fat content of $15.44 \%$., carbohydrate content of $72.77 \%$; crude fiber content of $1.96 \%$; antioxidant activity of $77.80 \mathrm{C} \%$.

\section{Suggestions:-}

1. Utilization of banana flour in food processing is still very rare, for it needs to be applied to various foodstuffs in households scale and industrial scale in order to support flour based food diversification program.

2. For further researcher it is suggested to analyze the shelf life and free fatty acid content of cooking products of banana flour with cinnamon powder addition. 


\section{References:-}

1. U.S Wheat Associate 1981. Pedoman Pembuatan Roti dan Kue. Djambatan. Jakarta.

2. Mulyati, S. 2005. Aneka Olahan Pisang.Trubus Agrisarana. Surabaya.

3. Satuhu, S. and A. Supriyadi. 1999. Budidaya Pengolahan dan Prospek Pisang. Penerbit Swadaya. Jakarta.

4. Hardiman. 1982. Tepung Pisang, Ciri Jenis, Cara Pembuatan, dan Resep Penggunaannya. Gajah Mada Press. Universitas Gajah Mada. Yogyakarta.

5. Rismunandar and Paimin.2001. Kayu Manis: Budi Daya dan Pengolahan. Penebar Swadaya. Jakarta.

6. Indah. 2013. Pengaruh Penambahan Konsentrasi Kulit Kayu manis (cassivera) Terhadap Teh Celup daun Sukun.Universitas Andalas. Padang.

7. Rohmah. 2010. Pengaruh pencampuran bubuk kopi Robusta Daun dan Cinnamon powder (Cassiavera). .Universitas Andalas. Padang.

8. Rukmana, R. 1999. Usaha Tani Pisang. Kanisius. Yogyakarta.

9. Manley, DJR. 2000. Teknology of Biscuit, Crackers, and Cookies. Ellis HorwoodLimited. Chiecester Publisher. United Kingdom

10. Pulungan, R. 2015. Pengaruh Penambahan Tepung Pisang Dan Tepung Kacang Hijau Terhadap Karakteristik Cookies Yang Dihasilkan. Teknologi Hasil Pertanian. Universitas Andalas. Padang.

11. BSN. 1995. SNI 01-3841-1995. Syarat Mutu Tepung Pisang, Badan Standarisasi Nasional. Jakarta

12. BSN. 2011. SNI 01-2973-2011. Syarat Mutu Cookies Dan Biskuit. Badan Standarisasi Nasional . Jakarta.

13. Winarno, F.G. 2004. Kimia Pangan dan Gizi. Jakarta. Gramedia Pustaka Umum. Jakarta.

14. Rismunandar. 1989. Kayu Manis. Penebar Swadaya, Jakarta. 